\title{
THE EFFECT OF PREMATURE EXTRACTION OF PRIMARY MOLARS ON SPATIAL CONDITIONS AND FORMATION OF MALOCCLUSION - A SYSTEMATIC REVIEW
}

\author{
Marta Gibas-Stanek, Bartłomiej W. Loster \\ Department of Ortodontics, Jagiellonian University, Cracow, Poland
}

\begin{abstract}
InTroduction: Premature loss of deciduous teeth is considered to be one of the local environmental factors interfering with normal development of the occlusion. Extraction of deciduous tooth before the time of its physiological exfoliation carries the risk of creation of unfavorable spatial changes in sagittal, transverse and vertical plane. Despite the undeniable role of well-preserved primary dentition in the development of occlusion in adulthood, there are still controversies regarding indications for implementation of space maintainers.

ОвјестіvEs: Analysis of available literature in terms of consequences of premature loss of deciduous molar teeth.

MATERIAL AND MEthods: The literature review was conducted in PubMed, EMBASE and Scopus databases in July 2017 basing on keyword "premature primary tooth loss". English and Polish-language magazines were taken into account without specifying the time frame.

RESULTS: In total, 20 papers were selected for further detailed analysis, of which 11 were based on longitudinal studies, 9 were cross-sectional studies (including 7 retrospective studies and 2 systematic literature reviews).

Conclusions: Premature extraction of the upper first primary molar may lead to buccal eruption of permanent canine as a consequence of more mesial eruption of first premolar. Increased risk of space loss within dental arch exists especially in case of coexistence of cusp to cusp relationship on first molars and leptoprosopic facial type. Consequences of losing lower first deciduous molar are less obvious. Extraction of second deciduous molars may result in much more serious disturbances related to mesial migration of first permanent molars, resulting in retention or abnormal eruption of second premolars. Repercussions of early loss of deciduous teeth are often visible only at the moment of eruption of permanent successors and depend on many variables, among which patient's age at the time of extraction, initial spatial conditions (crowding/spacing) and the number and type of lost teeth should be mentioned.
\end{abstract}

KEY wORDS: tooth loss, primary teeth, dental caries.

J Stoma 2018; 71, 5: 420-431

DOI: https://doi.org/10.5114/jos.2018.84765

\section{INTRODUCTION}

Despite increasing dental awareness of patients and their parents, as well as well-documented scientific reports on the role of deciduous teeth in the normal development of the stomatognathic system [1-3], the problem of tooth decay and premature loss of primary teeth has not lost its relevance. According to national epidemiological studies carried out in 2012 in Poland as a part of the "Monitoring of oral health" program, only $14.4 \%$ of 6-year-old

\section{JOURNAL OF STOMATOLOGY CZASOPISMO STOMATOLOGICZNE \\ AdDRESS For CORRESPONDENCE: Prof. Bartłomiej W. Loster, \\ Department of Orthodontics, Dental Institute, Faculty of Medicine, Jagiellonian University Medical College, 4 Montelupich St., 31-155 Cracow, Poland, e-mail: bw.loster@uj.edu.pl}


children had dentition that was free of caries [4]. In the group of 6-year-old children there was also a very low index of conservative treatment equal to 0.23 (where 0 means no teeth with caries were treated, and 1 means all teeth that had been decayed were treated) [5]. In addition to the direct complications of caries, such as pulpitis, abscesses or fistulas, loss of hard tissues of the deciduous teeth before the period of their physiological exfoliation implies significant problems in the area of developing occlusion [3, 6, 7]. At the same time, only $40.8 \%$ of the adult respondents were aware of the relationship between the loss of numerous deciduous teeth and the risk of permanent teeth movement and crowding [5].

The consequences of space deficiency due to early loss of deciduous molars often complicate the process of orthodontic treatment of the existing malocclusion and in many cases are the only indication for treatment. However, scientific reports are not consistent with the extent of complications and the time of their occurrence, raising in some cases the question about the necessity of using preventive measures in the form of space maintainers.

\section{OBJECTIVES}

The aim of the study was to analyze the reports of the scientific literature regarding the influence of premature loss of deciduous molars on formation of occlusal disorders.

\section{MATERIAL AND METHODS}

The literature review was performed in PubMed, EMBASE and Scopus databases in July 2017. English and Polish-language journals were taken into account without specifying the time frame. The index word used was "premature primary tooth loss". Only original articles were searched and as a criterion for inclusion in the study, the compliance of the information with the specific work objectives was evaluated.

\section{RESULTS}

Basing on the conducted research, 78 articles that qualified for further analysis were obtained. Works in a language other than Polish and English as well as articles not directly related to the subject of the review were excluded, obtaining 18 articles. Two articles from professional literature not present in the searched databases but consistent with the subject and methodology were also included ("Space reduction after the premature loss of a second molar-retrospective study" and "Mandibular dental arch dimensional changes following prematurely lost deciduous molars"), obtaining a total of 20 works, which are presented in Tables 1-4. The oldest of the se- lected articles is from 1965, the latest from 2017. Eleven papers are based on longitudinal studies (Tables 1 and 3), 9 are cross-sectional studies (Table 2), of which 7 are retrospective studies and the remaining 2 are systematic reviews of the literature. Five of the selected articles describe issues related only to premature loss of the upper first deciduous molars. In 1 article only consequences of early loss of lower first deciduous molars were examined and the effects of loss of both upper and lower first deciduous molars were also observed in 1 study. In 5 articles, the consequences of loss of both the first and second primary molars were investigated, while in the remaining 5 loss of deciduous molars and canines was considered. In 1 study, only the effect of losing secondary primary molars was studied.

Research groups were heterogeneous in terms of nationality, gender, size (the smallest group included 9 people, the largest 519 participants), age (from 4.1 to 15 years) and even social origin.

The most frequently used method involved measurements performed on models (14 works), while in other cases the data for analysis was obtained from a clinical examination.

In the group 519 Icelandic children in the dental maturity phase DS02, DS1 and DS2, examined during an epidemiological study in 1979, in 141 (27\%) there was a lack of at least one deciduous tooth caused by the necessity of early extraction [8]. Statistically, the premature loss was more often related to the lower arch. Polish research from 1988 showed absence of deciduous molars in $48 \%$ of children aged 5.5-6.5 years and in $49 \%$ at the age of 5.6-7.5 years [9]. "Monitoring of oral health" carried out in Poland in 2012 indicates a reduction of this percentage to $6.1 \%$ (in 6-year-old children) [4]. A study of 5-10-year-old children from Yemen (2016) reports on missing primary teeth in $40.54 \%$ of participants [10]. It also confirms greater frequency of premature extraction in the lower arch, where the second deciduous molar was missing the most often.

The number of studies performed to investigate the consequences of premature loss of primary first molars tells a lot about controversy related to this issue. It is commonly accepted that the loss of a deciduous tooth due to non-physiological reasons, especially before the period of appearance of a permanent successor in the oral cavity, carries the risk of loss of space in the dental arch. In the analyzed articles most of the attention was paid to the loss of the first upper molars.

Northway observed mesial inclination of the second deciduous molar as a consequence of extraction of the upper first deciduous molar, followed by eruption of the first premolar in a more mesial position than on the control side $[11,12]$. As a result, permanent canines erupted in a buccal position, so correlation with the formation of malocclusion and the necessity of orthodontic intervention is noticeable. However, this statement is in contradiction with Park's study [13], where no signifi- 


\begin{tabular}{|c|c|c|c|}
\hline 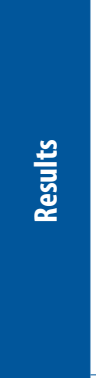 & 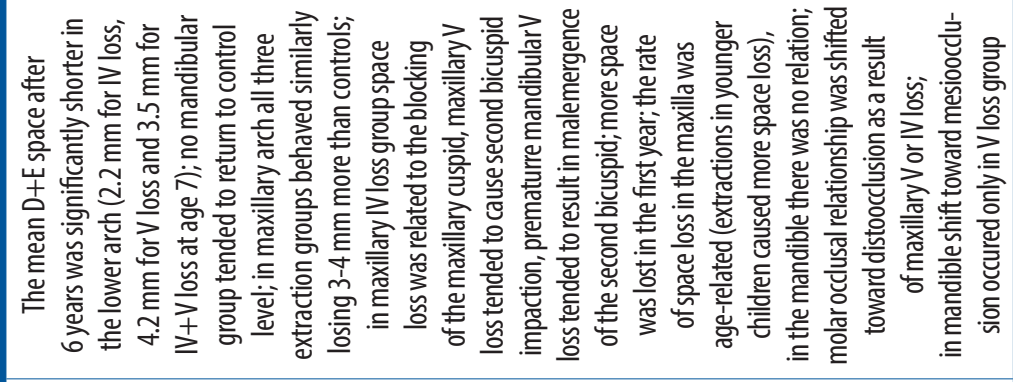 & 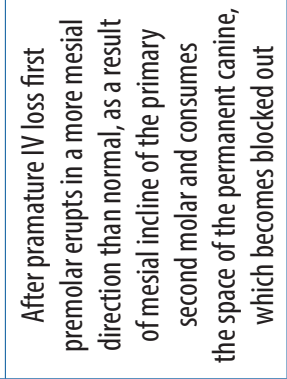 & 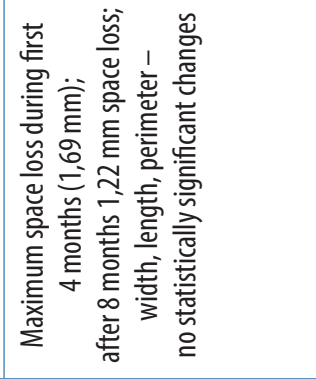 \\
\hline 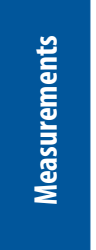 & 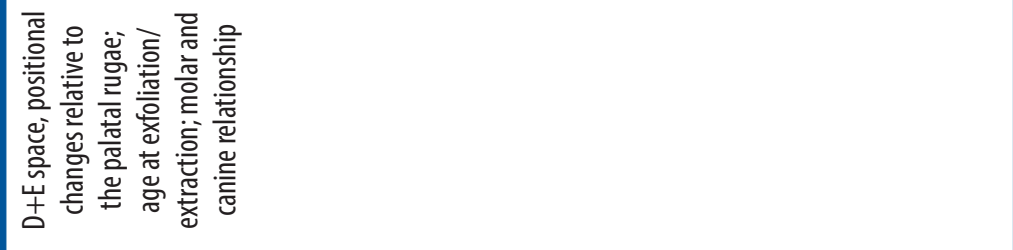 & 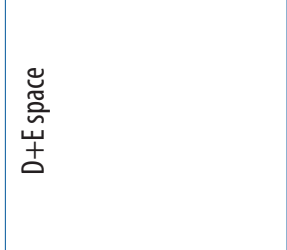 & 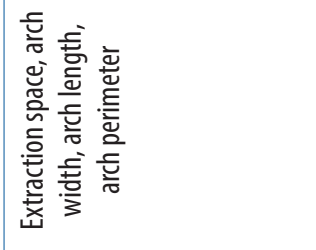 \\
\hline 홓 & 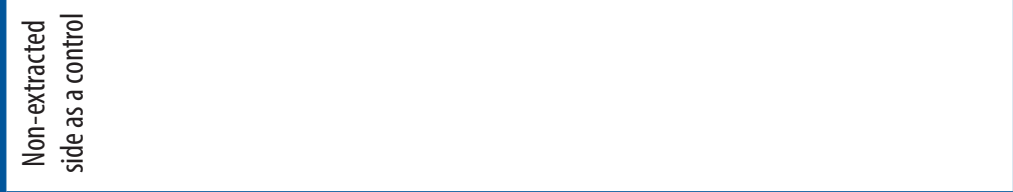 & 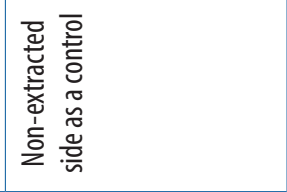 & 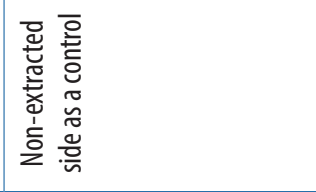 \\
\hline 흘 & 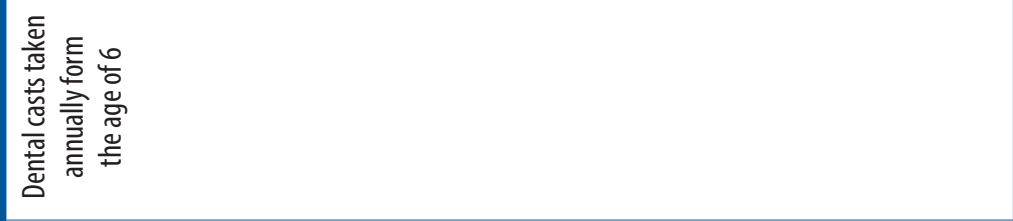 & 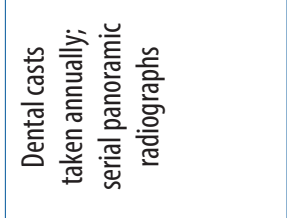 & 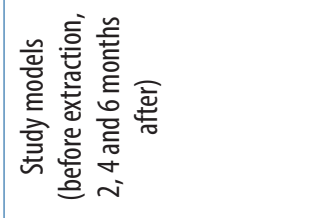 \\
\hline 急 & 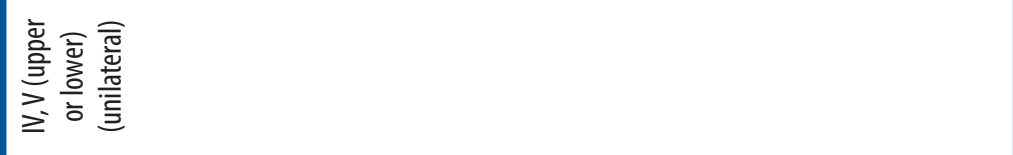 & 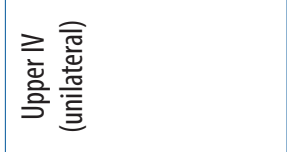 & 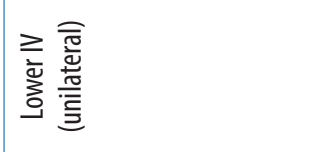 \\
\hline 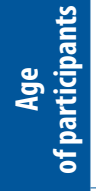 & 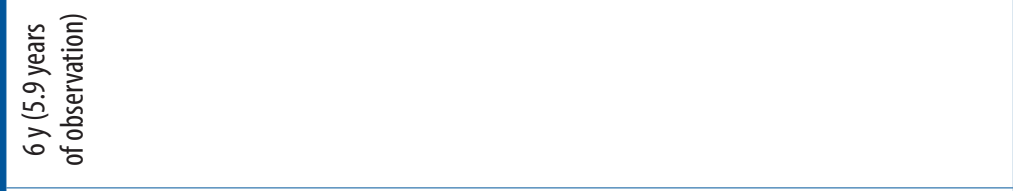 & 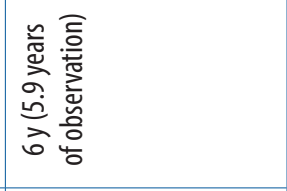 & àे \\
\hline & $\hat{o}$ & $m$ & m \\
\hline 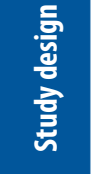 & 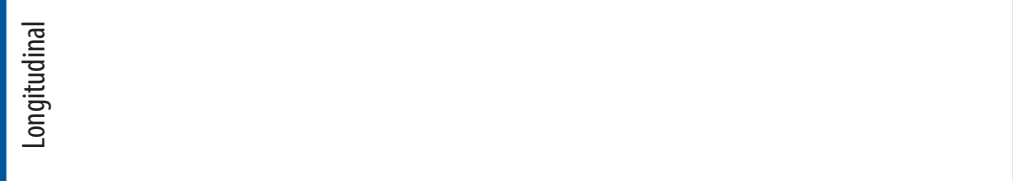 & 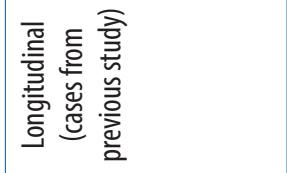 & 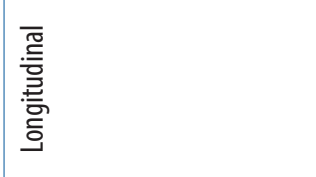 \\
\hline 总 & $\begin{array}{l}\text { 융 } \\
\text { 荧 }\end{array}$ & $\begin{array}{l}\text { 茔 } \\
\text { ్ㅣㅇ }\end{array}$ & 営 \\
\hline to. & 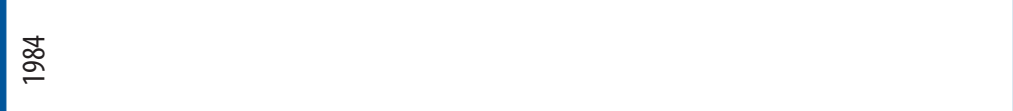 & 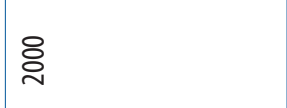 & ঃั \\
\hline$\stackrel{ \pm}{\Xi}$ & 总 & 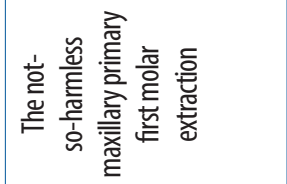 & 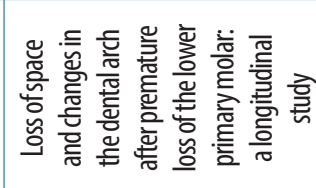 \\
\hline 毫 & 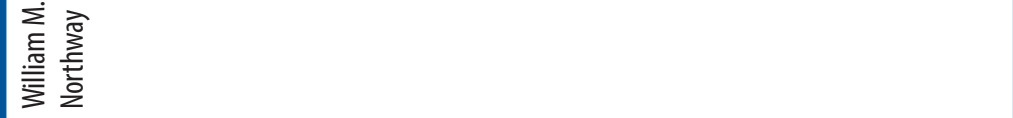 & 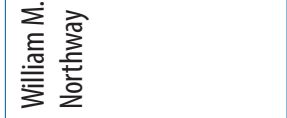 & 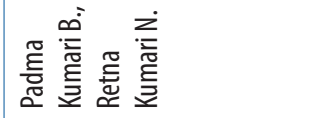 \\
\hline
\end{tabular}




\begin{tabular}{|c|c|c|c|c|c|}
\hline$\stackrel{\underline{\underline{z}}}{\underline{\underline{u}}}$ & 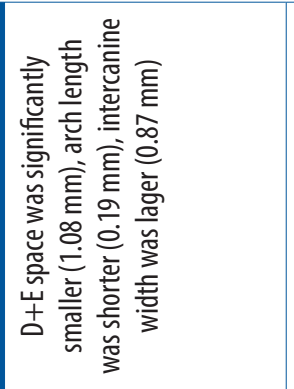 & 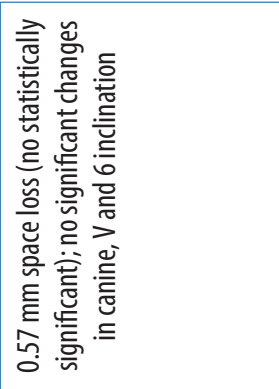 & 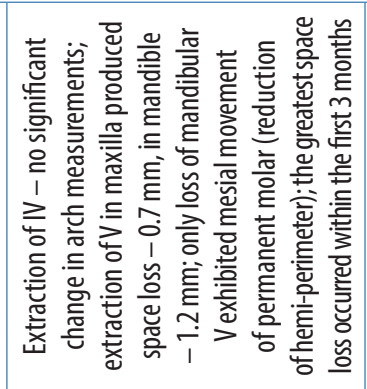 & 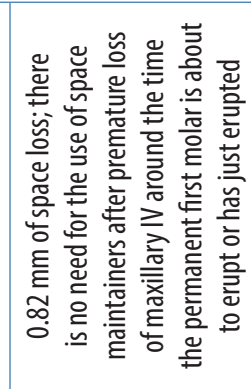 & 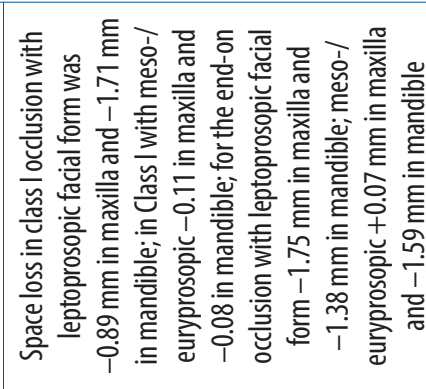 \\
\hline 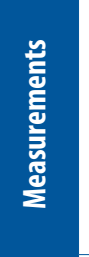 & 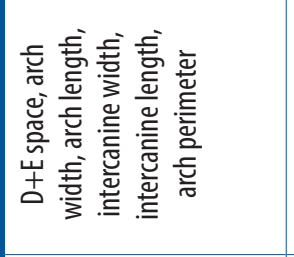 & 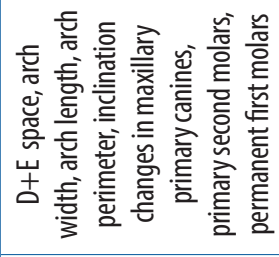 & 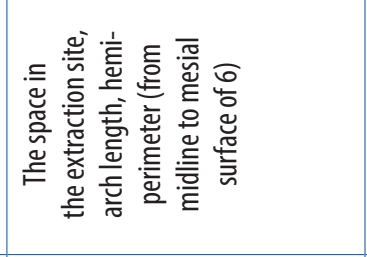 & 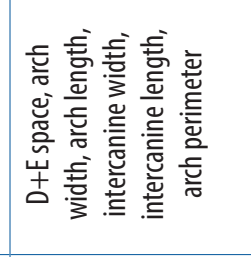 & 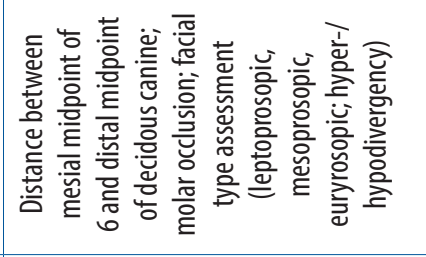 \\
\hline & 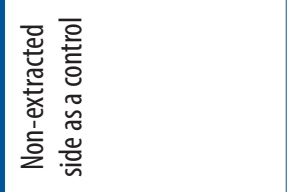 & 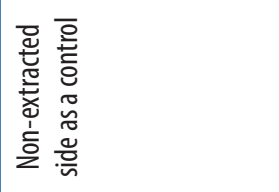 & 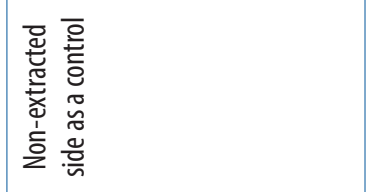 & 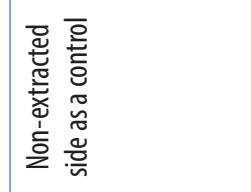 & 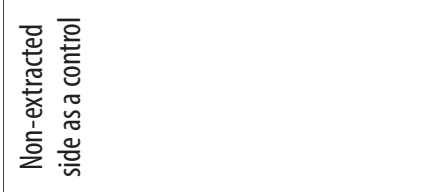 \\
\hline 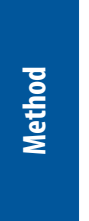 & 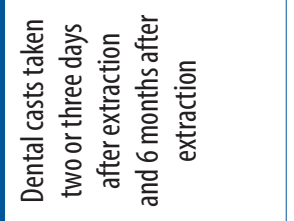 & 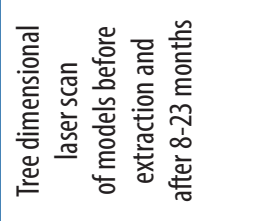 & 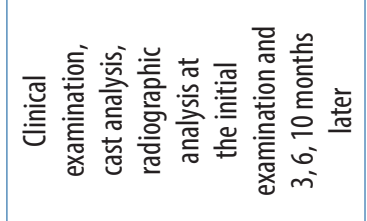 & 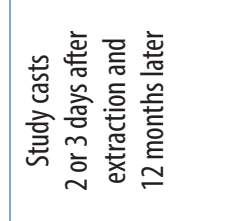 & 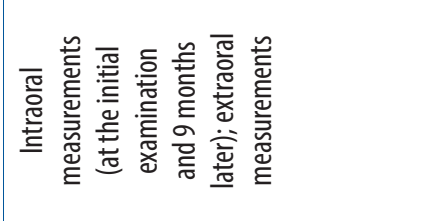 \\
\hline 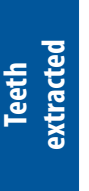 & 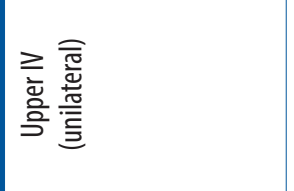 & 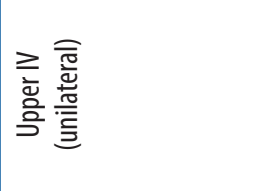 & 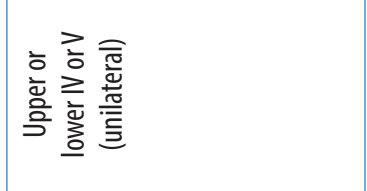 & 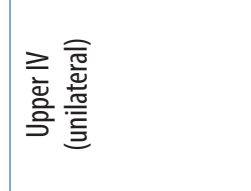 & 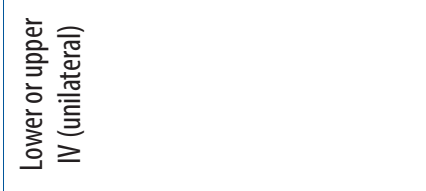 \\
\hline 暠 & $\underset{\substack{i \\
\stackrel{i}{+}}}{\stackrel{a}{i}}$ & 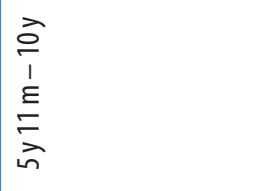 & वे & $\vec{\jmath}$ & 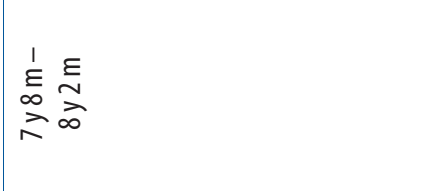 \\
\hline 意 & 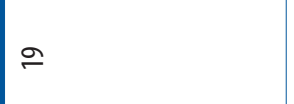 & $m$ & นn & $m$ & $\stackrel{\sim}{\sim}$ \\
\hline $\begin{array}{l}\frac{5}{\bar{y}} \\
\frac{y}{0} \\
\text { 홀 }\end{array}$ & 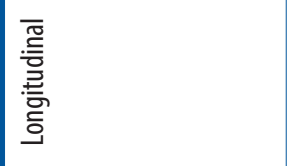 & 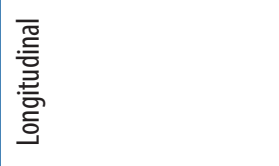 & 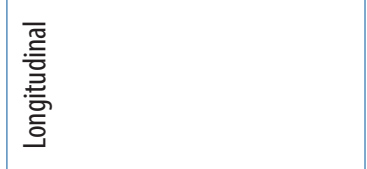 & 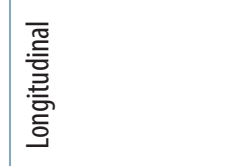 & 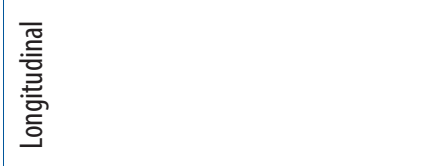 \\
\hline$\underline{E}$ & 墕 & 砉 & $\begin{array}{l}\overline{\overline{\mathbb{N}}} \\
\text { 离 }\end{array}$ & 嫣 & 芯 \\
\hline 方 & ڤે & ઠे & $\overline{\grave{n}}$ & $\overline{\bar{\sigma}}$ & $\stackrel{\operatorname{nn}}{\grave{n}}$ \\
\hline$\stackrel{\Xi}{\Xi}$ & 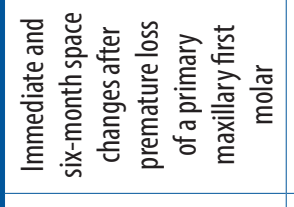 & 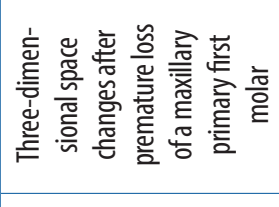 & 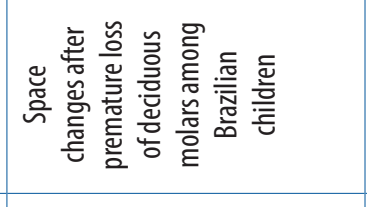 & 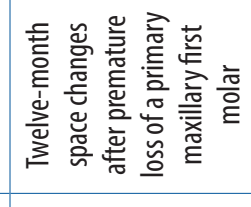 & 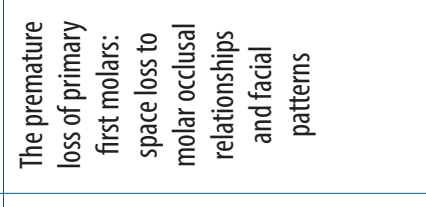 \\
\hline & 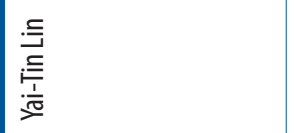 & 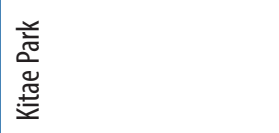 & 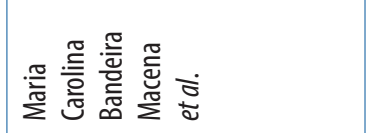 & 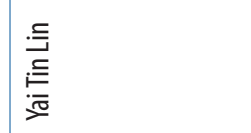 & 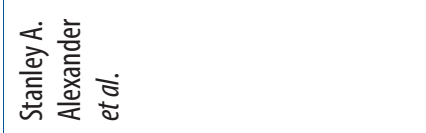 \\
\hline
\end{tabular}




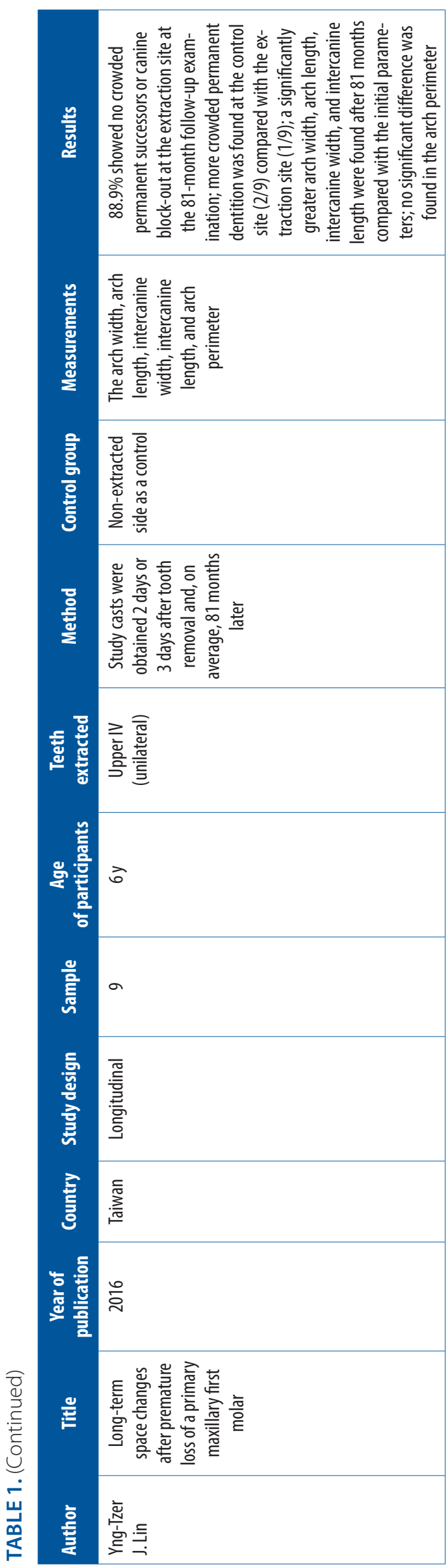

cant changes were observed in the inclination of the second upper deciduous molar, the first permanent molar and deciduous canine, and average space loss $(0.57 \mathrm{~mm})$ was not statistically significant. It should be emphasized that all participants of Park's study had a class I molar relation. Lin also did not observe changes in the position of the upper molars, but he noticed distal dislocation of the primary canines with reduction of the $\mathrm{D}+\mathrm{E}$ space by $1.08 \mathrm{~mm}$ after 6 months and $0.82 \mathrm{~mm}$ after 12 months $[14,15]$. After 81 months in $88.9 \%$ of cases crowding on the extraction side was not observed at the stage of permanent dentition [16]. Despite the loss of space, according to the authors of the study, existing changes are not clinically significant and there is no need to use a space maintainer, provided that the first permanent molar is erupted, or will appear in the mouth in the nearest future. Macena also did not observe significant changes in the upper dental arch after measuring the space in the extraction site and the length of the arch and comparing it to the control side [17]. Alexander expanded the study to examine the correlation between the amount of space lost after extraction and molar relation and type of face [18]. Assessing the ratio of the length of the section determined by the skin points zygion to the section nasion-gnathion, he distinguished the leptoprosopic face (ratio 0.75 or less), mesoprosopic face (ratio 0.76-0.79) and euryprosopic face (ratio 0.8 or greater). The largest loss of space in the maxilla occurred in the case of the cusp-to-cusp relationship and leptoprosopic face $(1.75 \mathrm{~mm})$, while the lowest occurred in patients with class I and meso-/ euryprosopic face type $(0.11 \mathrm{~mm})$, which may suggest that normal intercuspation and moderate and wide face type minimize the risk of losing space.

A less obvious correlation exists in the case of the lower arch. Kumari in his study focused on premature extraction of lower first deciduous molars, showing the greatest loss of space after the first 4 months $(1.69 \mathrm{~mm})$, resulting mainly from the distal drift of canines [19]. Interestingly, after 8 months of extraction, the loss of space was only $1.22 \mathrm{~mm}$. Also these authors question the necessity of using a space maintainer in the case of extraction of the first primary molar in the mandible. A different opinion is represented by Al-Dulayme, who observed distal displacement of the lower canine in the $1 \mathrm{~mm}$ range, as well as mesial migration of second deciduous molar and first permanent molar $(2 \mathrm{~mm})$ [20]. In addition, the first permanent molar inclined lingually. Due to the intensification of observed changes, this author recommends the use of space maintainers also in the case of premature loss of the first molar in the mandible.

Magnusson in an epidemiological study of Icelandic children recorded the largest loss of space at the extraction site after premature loss of second deciduous molars [8]. Northway measuring the distance $\mathrm{D}+\mathrm{E}$ on average 5.9 years after extraction of the primary tooth 


\begin{tabular}{|c|c|c|c|}
\hline 䓌 & 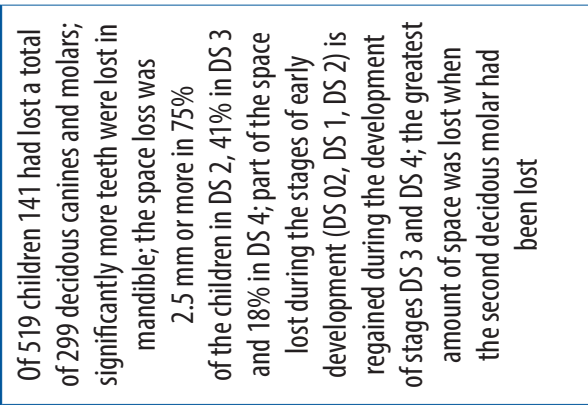 & 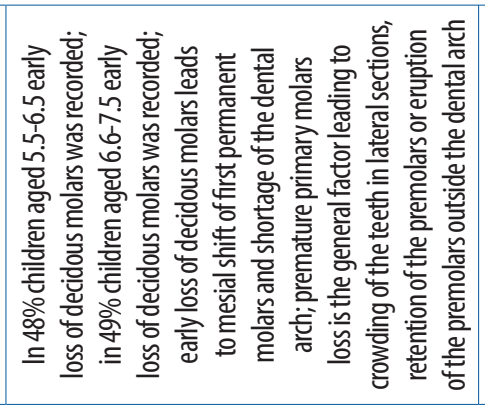 & 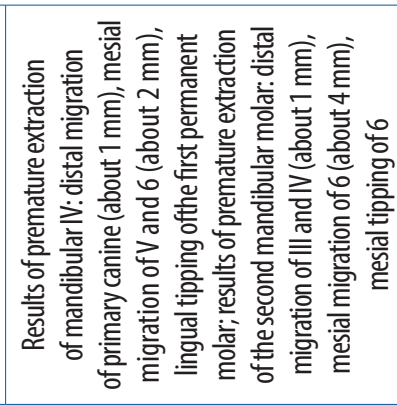 \\
\hline 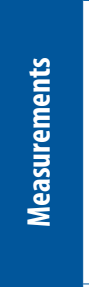 & 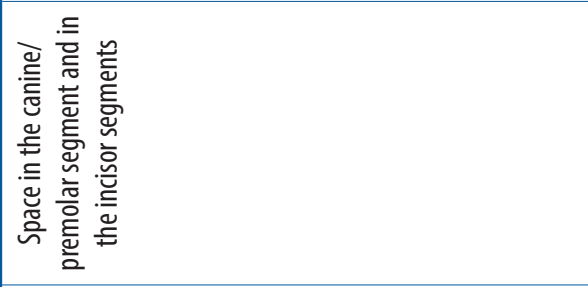 & 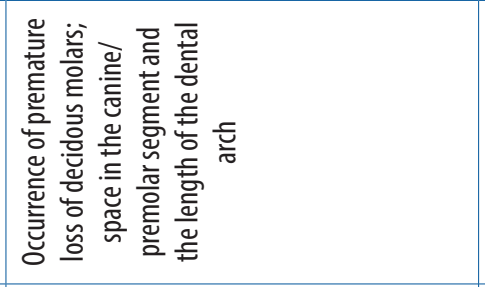 & 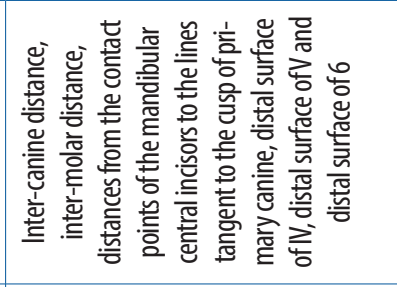 \\
\hline & 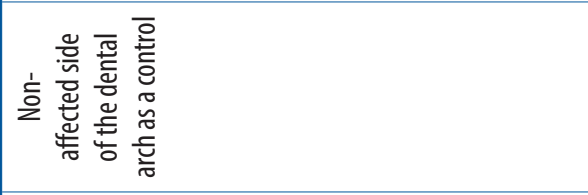 & 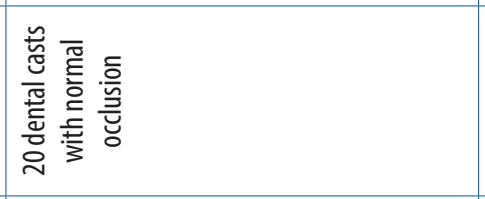 & 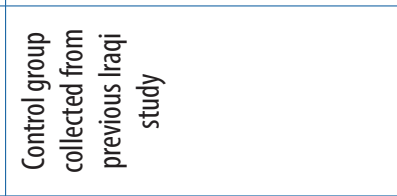 \\
\hline 흘 & 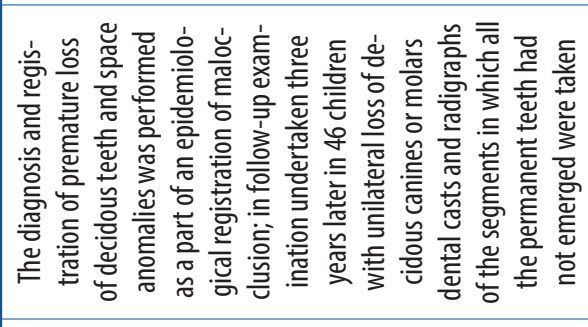 & 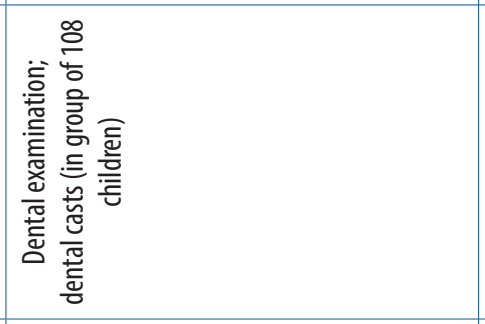 & 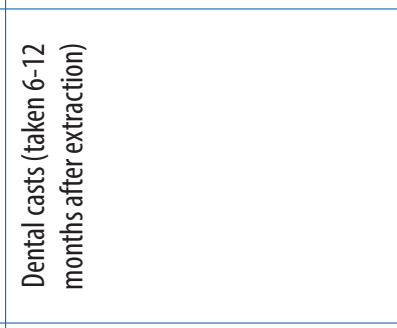 \\
\hline & $\stackrel{\geqq}{\equiv}$ & $\geqq$ & ऐo \\
\hline 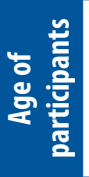 & 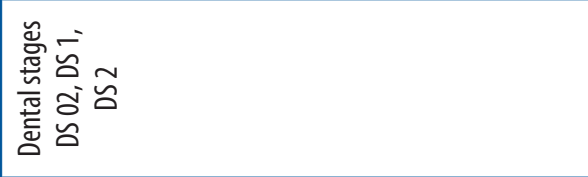 & 余 & àे \\
\hline & in & $\stackrel{D^{\circ}}{\circ}$ & in \\
\hline 흘 & 岕 总 & 岕 胥 & 岕 \\
\hline 를 & 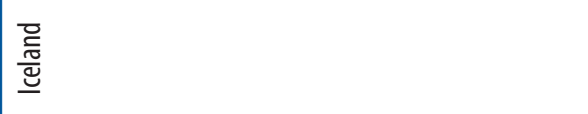 & $\begin{array}{l}\text { 흠 } \\
\text { 홍 }\end{array}$ & 휼 \\
\hline 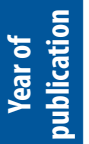 & ڤิ & $\stackrel{\infty}{\stackrel{\circ}{\sigma}}$ & 离 \\
\hline$\stackrel{\Xi}{E}$ & 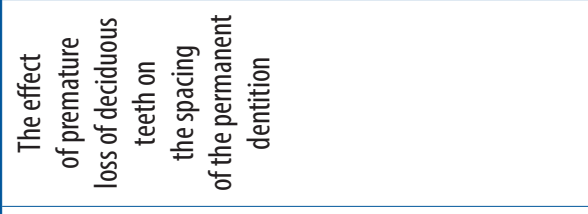 & 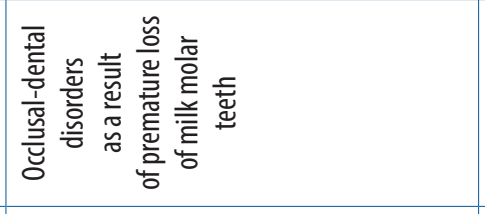 & 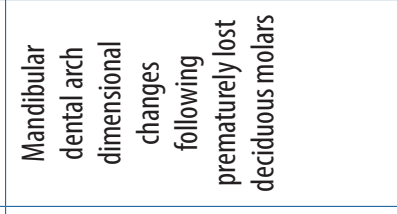 \\
\hline 홀 & 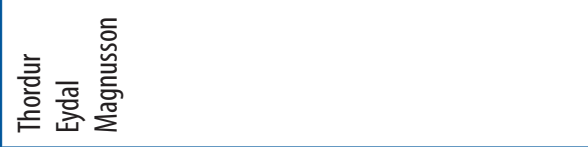 & 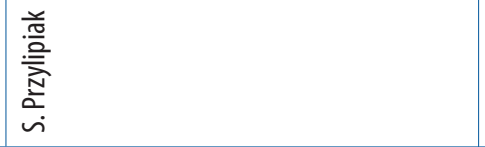 & 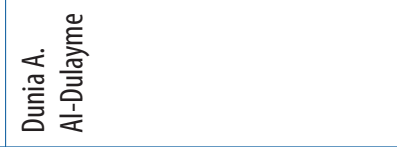 \\
\hline
\end{tabular}




\begin{tabular}{|c|c|c|c|}
\hline 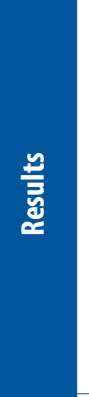 & 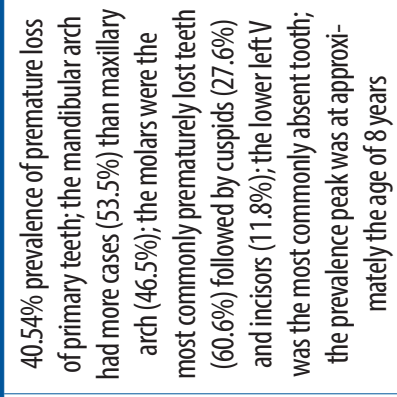 & 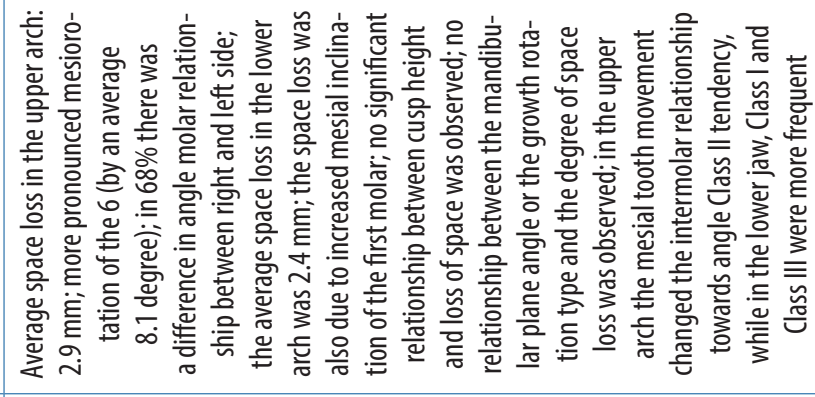 & 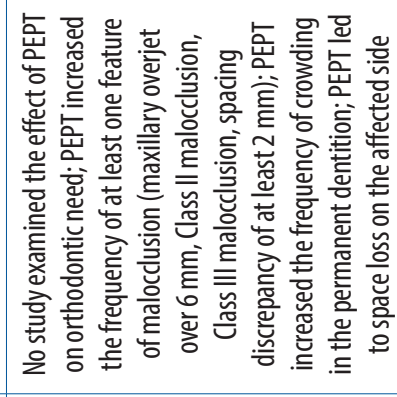 \\
\hline 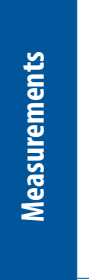 & 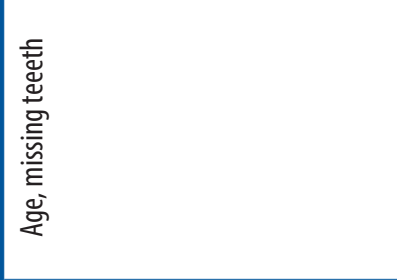 & 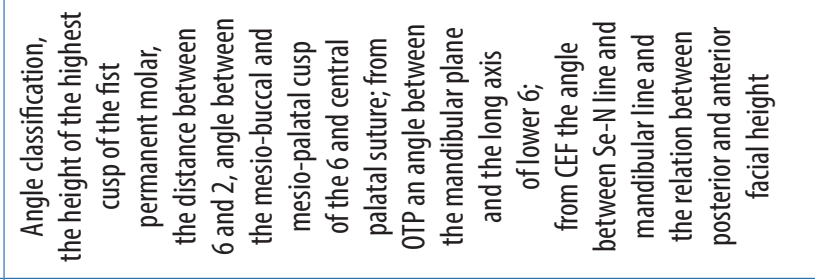 & \\
\hline $\begin{array}{l}\text { 을 } \\
\text { 흫 } \\
\text { 을 }\end{array}$ & & 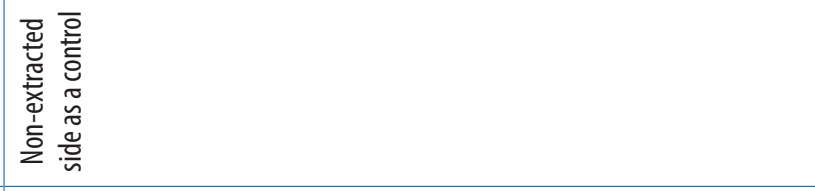 & \\
\hline 产言 & 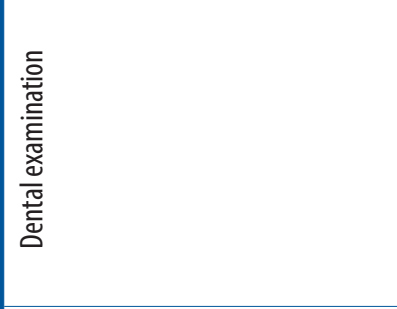 & 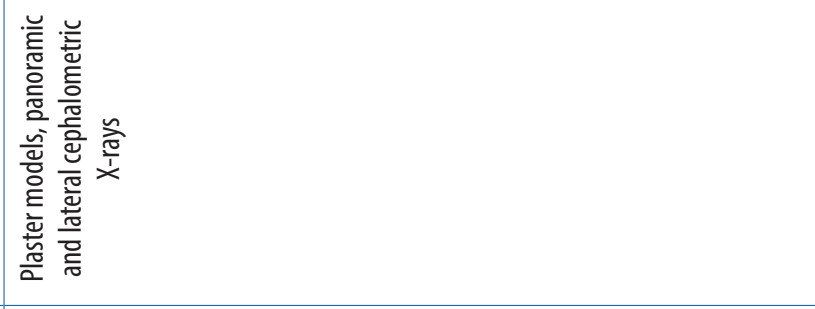 & 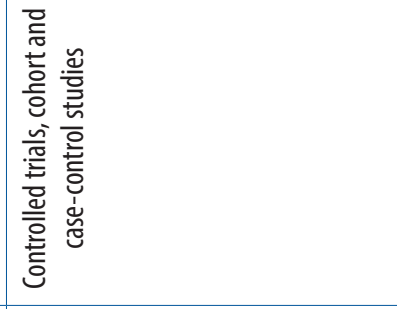 \\
\hline 焉 & 旁焉 & 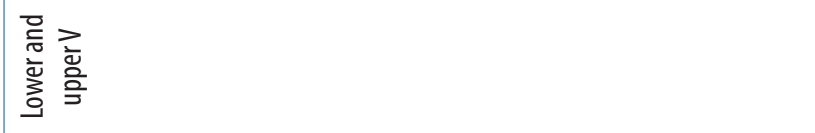 & \\
\hline 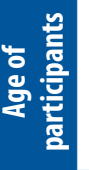 & 음 & 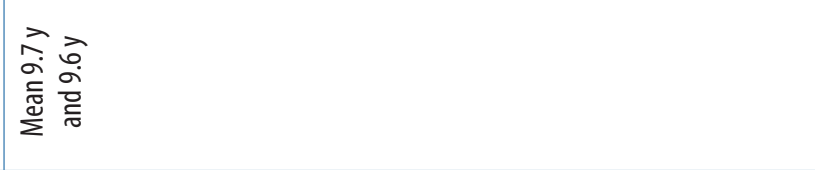 & \\
\hline 总 & $\stackrel{\llcorner}{\infty}$ & 㶽 7 & $\circ \frac{\mathscr{m}}{\underline{\underline{\underline{n}}}}$ \\
\hline 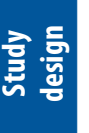 & 岕总 & 岕悹 & 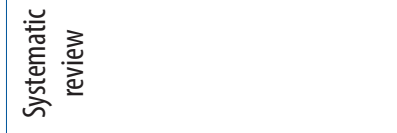 \\
\hline & 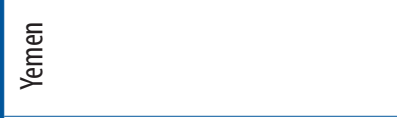 & 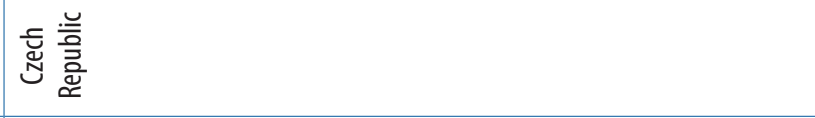 & 兰 \\
\hline 顿 & $\stackrel{ }{\check{2}}$ & $\stackrel{\circ}{\check{D}}$ & 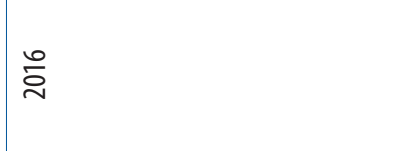 \\
\hline 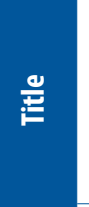 & 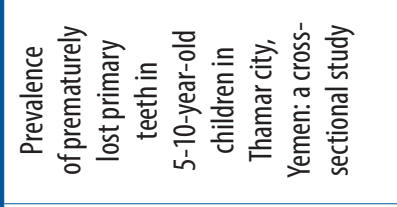 & 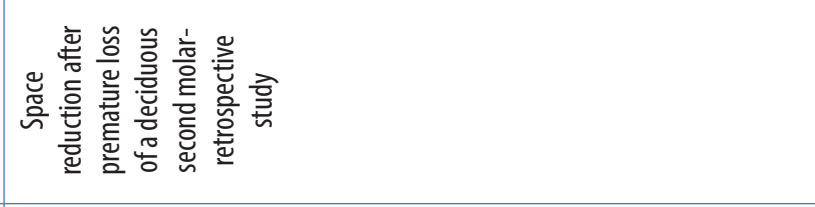 & 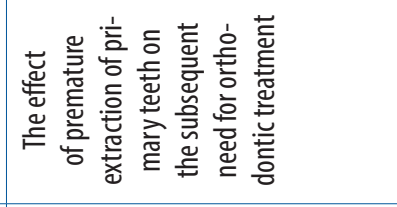 \\
\hline 毫 & 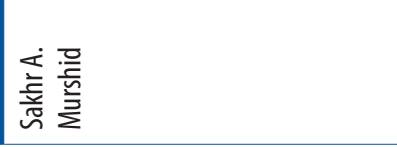 & $\begin{array}{l}\text { 胥 } \\
\text { 产 } \\
\text { 홍 }\end{array}$ & \begin{tabular}{|l}
$\overline{\mathrm{g}}$ \\
产 \\
$\bar{z}$
\end{tabular} \\
\hline
\end{tabular}




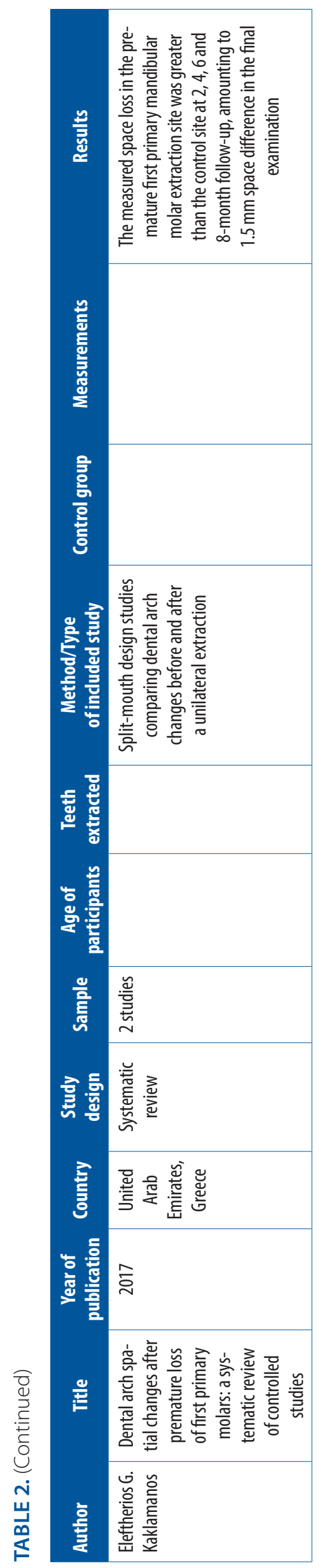

\begin{tabular}{|c|c|c|}
\hline 层 & 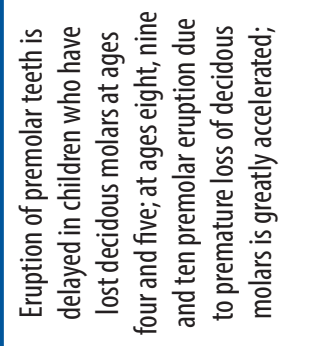 & 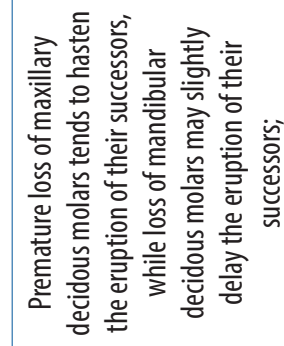 \\
\hline 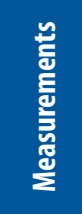 & 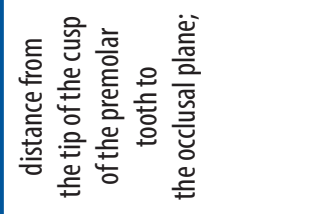 & 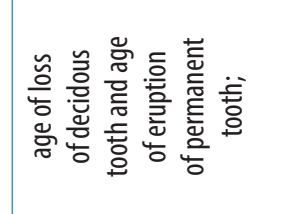 \\
\hline $\begin{array}{l}\text { 흔 } \\
\text { 흘 } \\
\text { 흥 }\end{array}$ & 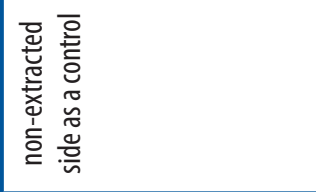 & 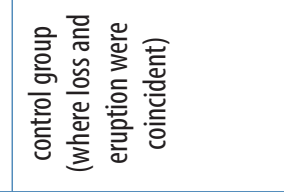 \\
\hline $\begin{array}{l}\text { 흘 } \\
\text { 휼 }\end{array}$ & 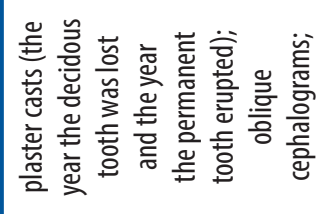 & 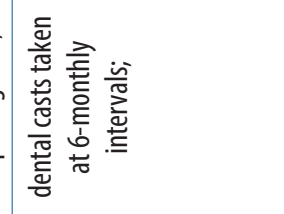 \\
\hline 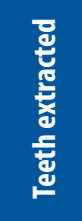 & 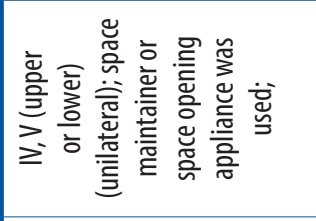 & 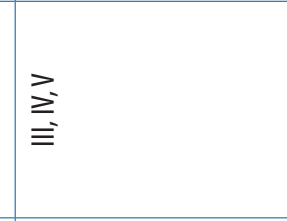 \\
\hline 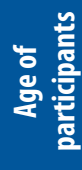 & 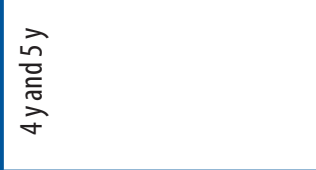 & 离 \\
\hline 竧 & $\widetilde{\sigma}$ & $\stackrel{2}{\beth}$ \\
\hline 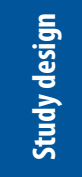 & 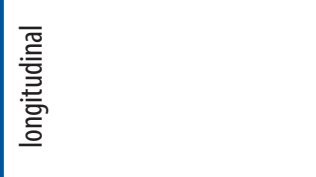 & $\begin{array}{l}\text { 즐 } \\
\text { 言 } \\
\text { 言 } \\
\text { 恶 }\end{array}$ \\
\hline 言 & $\begin{array}{l}\text { 쥬 } \\
\text { 퓨 }\end{array}$ & 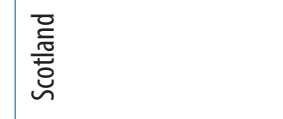 \\
\hline 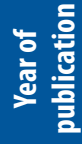 & $\stackrel{2}{\circ}$ & $\stackrel{\circ}{\stackrel{一}{9}}$ \\
\hline 黑 & 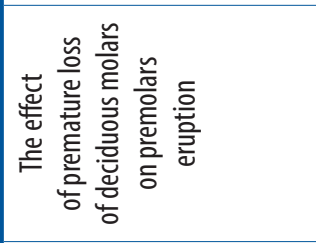 & 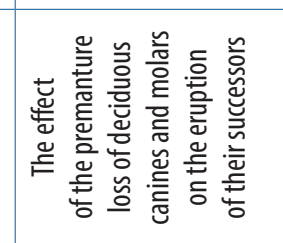 \\
\hline 意 & 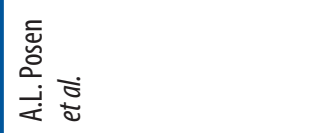 & 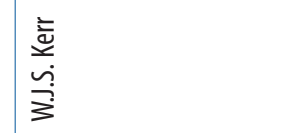 \\
\hline
\end{tabular}




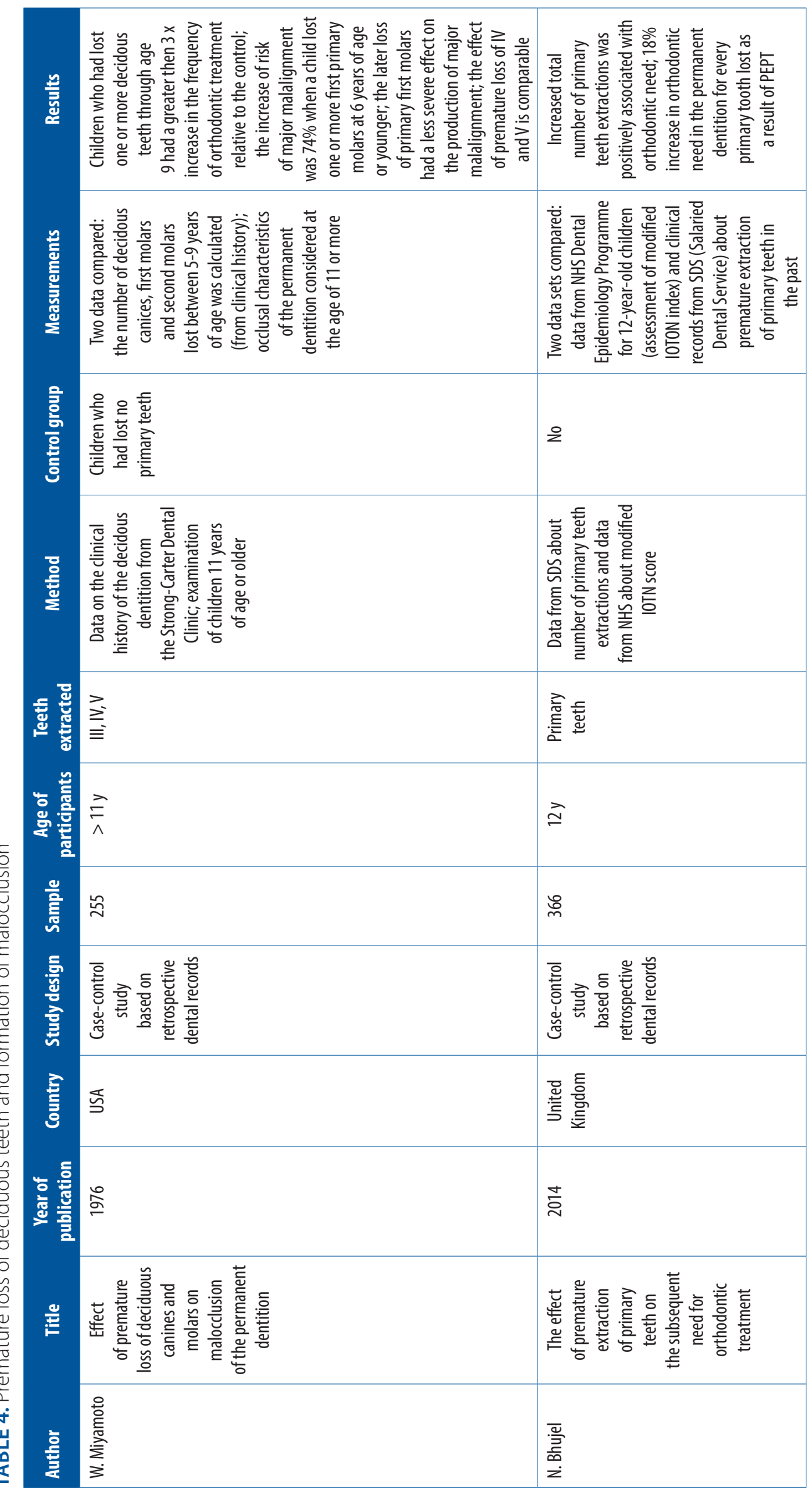


observed a $3.7 \mathrm{~mm}$ loss of space after premature extraction of the second deciduous molar in the maxilla and 3-4 $\mathrm{mm}$ after extraction of the lower second deciduous molar in the mandible when compared to the control side [11]. In both cases, the main cause of space deficiency was mesial drift of the first permanent molar, which in the upper arch led to distal molar relation, and in the lower arch to mesial relation. The most significant changes took place during the first year after extraction. In addition, in the case of the upper arch, a correlation was observed between the time of loss of the deciduous tooth and the extent of mesial drift, where early extraction caused more intensive mesialization of the first permanent molar. As a consequence of reducing the $\mathrm{D}+\mathrm{E}$ distance it is probable that the upper and lower second premolar will erupt in the incorrect position or will not erupt. Pokorna during at least a 6-month observation period after second deciduous molar extraction reported an average loss of space of $2.9 \mathrm{~mm}$ in the upper arch and $2.4 \mathrm{~mm}$ in the lower arch [21]. A different mechanism of formation of changes was also noted: the first lower permanent molar after premature loss of the second mandibular deciduous molar tipped mesially, while the upper one rotated mesially 8.1 degrees on average. Premature loss of the second molar also changed the relation within the first permanent molars on the extraction side towards class II in the case of tooth loss in the upper jaw and class I and III in the case of premature tooth loss in the mandible. The magnitude of the shifts remained unaffected either by the height of the cusps of the first permanent molar or the vertical skeletal jaw relation. Al-Dulayme observed in the measurements performed from 6 to 12 months after extraction of the second deciduous molar in the mandible both mesial migration of the first permanent molar $(2 \mathrm{~mm})$ and distal drift of the primary canine and first primary molar $(1 \mathrm{~mm})$ [20]. Slightly different results were obtained by Macena et al. during 10-month observation of Brazilian children [17]. Premature loss of the second deciduous molar resulted only in $1.2 \mathrm{~mm}$ of space loss in the lower arch and $0.7 \mathrm{~mm}$ in the upper arch, and the largest changes occurred during the first 3 months after extraction.

Posen reports on the correlation between the age of deciduous tooth loss and the time of eruption of the permanent successor [22]. According to the author, extraction of the primary molar at the age of 4-5 years causes delayed eruption of premolars, while in the case of extraction at the age of 8-10 years, eruption of the permanent successor is significantly accelerated. Kerr observed separate phenomena for the mandible and maxilla [23]. Premature loss of upper deciduous molars resulted in faster eruption of premolars than on the control side, while in the case of primary lower molars, early extraction led to delayed eruption of permanent successors.

There are few reports directly related to the relationship between premature loss of deciduous teeth and the need for orthodontic treatment in permanent dentition. Bhujel observed a positive correlation between the need for orthodontic treatment determined by the IOTN index and premature extraction of primary teeth [24]. Results of the study suggest that each prematurely removed deciduous tooth increased the need of orthodontic treatment by $18 \%$. According to Miyamoto's work, children who lost at least one primary tooth before the age of 9 were treated three times more often than children from the control group [25]. Younger age of the patient at the moment of tooth extraction predisposed to formation of a more severe disorder, but there was no difference between the consequences of losing first and second molars.

\section{DISCUSSION}

Comparison of the research results quoted in the above review faces numerous difficulties, due to discrepancies in the age of the participants, type of teeth lost, as well as chosen research methods and reference points required to perform linear measurements. Nevertheless, the authors agree in terms of higher frequency of premature extraction in the lower arch, where the second primary molar was lost the most often [8-10]. This coincides with reports on the prevalence of caries in deciduous dentition, where a higher risk exists in the case of the lower molars, especially the second ones. Increased susceptibility to dental caries of these teeth probably results from the specific anatomy of their occlusal surface characterized by deeper fossils and fissures and leads to their loss more frequently than in the case of earlier erupting first molars [26]. Summing up the findings from cited studies about the premature loss of first deciduous molars, it can be assumed that a space maintainer should be considered in patients with an unerupted first permanent molar or cusp-to-cusp contact, because mesial forces acting during permanent teeth eruption tend to accelerate space loss within the dental arch [18]. In addition, there is a greater risk of unfavorable spatial changes in the lower arch, which may occur both as a result of the mesial migration of the posterior teeth and even more significant distal drift of the anterior teeth $[19,27]$. This phenomenon can be explained by the influence of forces arising during eruption of permanent incisors on the distal shift of deciduous canines. It means that resulting changes also depend on the dental age at the time of tooth loss [13].

In the case of the upper jaw, taking into account measurements performed on models, there was no loss of space due to mesialization of posterior teeth and only distal drift of primary canines occurred, so the need for space maintainers in the maxillary arch is often negated [13-16]. At the same time Northway noted in 11 out of 13 cases vestibular retention of a permanent canine, which occurred as a result of loss of space in the arch 
due to more mesial eruption of the first premolars than on the control side $[11,12]$.

The second deciduous molars, determining the position of eruption of the first permanent molars and being more responsible for maintaining leeway space, seem to play an even more important role in formation of correct occlusion. According to the opinion of some authors, extraction of a second deciduous molar before first permanent molar eruption may even lead to complete closure of the space as a result of its mesial migration [28]. However, the amount of space lost should be related to the dimension of leeway space, which is larger in the mandibular arch. In this context, some authors consider loss of the lower second deciduous molars to be less burdened with negative consequences and suggest greater need for space maintainers in the upper jaw [21].

The mechanism of losing space after second deciduous molar extraction in the maxilla and mandible that often leads to the retention of second premolars is explained by both mesial shift of the first permanent molar and more distal eruption of the first premolar in comparison with physiological teeth exfoliation [11]. Moreover, changes in the sagittal plane are accompanied by transverse displacements: mesial rotation of the upper first permanent molar (although the magnitude of the rotations varies among studies from $0.67^{\circ} \pm 3.51^{\circ}$ to $\left.8.1^{\circ} \pm 5.8^{\circ}\right)[21,29]$ and lingual inclination of the lower first permanent molar resulting in reduction of posterior width of the lower arch [20]. Most of the cited studies refer to measurements performed within the period of dental maturity DS2 M1, where the only erupted permanent teeth are the first molars and central and lateral incisors. This may lead to underestimation of the role of loss of deciduous molars in the formation of occlusion due to the omission of changes occurring during eruption of permanent successors in the resistance zones, such as variation of the inclination of the first premolar, or accelerated or delayed eruption of permanent teeth in the area of premature loss. It seems to be impossible to demonstrate actual changes occurring after premature loss of primary molars in the context of existing scientific reports due to ethical reasons. Each case of premature loss of a deciduous tooth should be recorded and individually assessed in terms of orthodontic treatment needed to maintain a sufficient amount of space or restore missing space. The decision about leaving the patient without any orthodontic intervention may be justified only in the case of satisfactory spatial conditions or planned extraction treatment in the future.

\section{CONCLUSIONS}

Premature loss of deciduous teeth in many cases has a detrimental influence on forming occlusion. The most frequently reported complications include loss of space leading to vestibular canine eruption and retention or palatal/lingual eruption of a second premolar. Other observed disorders are change in molar relation, mesial rotation of the upper first permanent molar and mesial tipping of the lower one. Delayed or premature eruption of permanent successors is also the result of early extraction of primary teeth. The severity of disturbances depends on many variables, including child's age at the time of extraction, initial amount of space in the dental arch (spacing/crowding), and the type and amount of teeth extracted. Available reports do not provide precise guidelines regarding indications for application of space maintainers. Each case requires individual evaluation and selection of a treatment method consistent with current scientific reports.

\section{CONFLICT OF INTEREST}

The authors declare no potential conflicts of interest with respect to the research, authorship, and/or publication of this article.

\section{References}

1. Silva LP, Gleiser R. Occlusal development between primary and mixed dentitions: a 5-year longitudinal study. J Dent Child (Chic) 2008; 75: 287-294.

2. Barros SE, Chiqueto K, Janson G, Ferreira E. Factors influencing molar relationship behavior in the mixed dentition. Am J Orthod Dentofacial Orthop 2015; 148: 782-792.

3. Ackerman JL, Proffit WR. Preventive and interceptive orthodontics: a strong theory proves weak in practice. Angle Orthod 1980; 50: $75-87$

4. „Monitoring Zdrowia Jamy Ustnej” 2012.

5. „Monitoring Zdrowia Jamy Ustnej” 2010.

6. Rożniatowski P, Piróg-Bednarska A, Kobylińska A, et al. Kliniczne konsekwencje nieleczonej próchnicy wczesnego dzieciństwa u dzieci z wysokim ryzykiem próchnicy w dużym mieście w Polsce. J Stoma 2016; 69(6): 620-630.

7. Bhujel N, Duggal MS, Day PF. The effect of premature extraction of primary teeth on the subsequent need for orthodontic treatment. Eur Arch Paediatr Dent 2016; 17: 423-434.

8. Magnússon TE. The effect of premature loss of deciduous teeth on the spacing of the permanent dentition. Eur J Orthod 1979; 1: 243-249.

9. Przylipiak S, Herud B, Perzyńska K, et al. Zaburzenia zgryzowo-zębowe jako następstwo przedwczesnej utraty trzonowych zębów mlecznych. Czas Stom 1988; 41: 516-522.

10. Murshid SA, Al-Labani MA, Aldhorae KA, Rodis OM. Prevalence of prematurely lost primary teeth in 5-10-year-old children in Thamar city, Yemen: a cross-sectional study. J Int Soc Prev Community Dent 2016; 6: 126-130.

11. Northway WM, Wainright RL, Demirjian A. Effects of premature loss of deciduous molars. Angle Orthod 1984; 54: 295-329.

12. Northway WM. The not-so-harmless maxillary primary first molar extraction. J Am Dent Assoc 2000; 131: 1711-1720.

13. Park K, Jung DW, Kim JY. Three-dimensional space changes after premature loss of a maxillary primary first molar. Int J Paediatr Dent 2009; 19: 383-389.

14. Lin YT, Lin WH, Lin YT. Twelve-month space changes after premature loss of a primary maxillary first molar. Int J Paediatr Dent 2011; 21: 161-166.

15. Lin YT, Lin WH, Lin YT. Immediate and six-month space changes after premature loss of a primary maxillary first molar. J Am Dent Assoc 2007; 138: 362-368. 
16. Lin YTJ, Lin YT. Long-term space changes after premature loss of a primary maxillary first molar. J Dent Sci 2017; 12: 44-48.

17. Macena MC, Tornisiello Katz CR, Heimer MV, et al. Space changes after premature loss of deciduous molars among Brazilian children. Am J Orthod Dentofacial Orthop 2011; 140: 771-778.

18. Alexander SA, Askari M, Lewis $P$. The premature loss of primary first molars: space loss to molar occlusal relationships and facial patterns. Angle Orthod 2015; 85: 218-223

19. Kumari PB, Kumari RN. Loss of space and changes in the dental arch after premature loss of the lower primary molar: a longitudinal study. J Indian Soc Pedod Prev Dent 2006; 24: 90-96.

20. AL-Dulayme DA, AL-Khannaq MR. Mandibular dental arch dimensional changes following prematurely lost deciduous molars. JODR 2014; 2: 22-28.

21. Pokorná H, Marek I, Kucera J, Hanzelka J. Space reduction after premature loss of a deciduous second molar- retrospective study. OSR-JDMS 2016; 15: 1-8.

22. Posen AL. The effect of premature loss of deciduous molars on premolar eruption. Angle Orthod 1965; 35: 249-252.

23. Kerr WJS. The effect of the premature loss of deciduous canines and molars on the eruption of their successors. Eur J Orthod 1980 2: 123-128.

24. Bhujel N, Duggal M, Munyombwe T, et al. The effect of premature extraction of primary teeth on the subsequent need for orthodontic treatment. Eur Arch Paediatr Dent 2014; 15: 393-400.

25. Miyamoto W, Chung CS, Yee PK. Effect of premature loss of deciduous canines and molars on malocclusion of the permanent dentition. J Dent Res 1976; 55: 584-590.

26. Saravanan S, Madivanan I, Subashini B, Felix JW. Prevalence pattern of dental caries in the primary dentition among school children. Indian J Dent Res 2005; 16: 140-146.

27. Kaklamanos EG, Lazaridou D, Tsiantou D, et al. Dental arch spatial changes after premature loss of first primary molars: a systematic review of controlled studies. Odontology 2017; 105: 364-374.

28. Nunn R, Murray A, Sandler J. Loss of deciduous teeth - is timing important to the GDP? Dent Update 2011; 38: 55-58, 61-64.

29. Linder-Aronson S. The effect of loss of deciduous teeth; a biometric study in 14- and 15-years-olds. Acta Odontologica Scandinavica $1960 ; 18$ : 101-122. 